\title{
A review on secondary metabolites, pharmacological status and phytoremediation to treat water hyacinth
}

Mohan J. ${ }^{*}$, Mohan N. ${ }^{1}$, Narendra Babu Shakya ${ }^{1}$, Amit pandey² \& Raghvendra Chauhan $^{3}$

1Department of Botany, D.A-V. College, Kanpur,

2Department of Botany, Bundelkhand University, Jhansi, India.

${ }^{3}$ Department of Mechanical Engineering, MIET Meerut,

Received: 2/20/2018; Revised: 3/2/2018; Accepted: 3/9/2018

\begin{abstract}
Eichhornia crassipes (Mart.) Solms (Water hyacinth), an oceanic lasting herb display All around the world, need a heap from claiming metabolites. Extracts, and additionally immaculate exacerbates disconnected starting with this plant, have been showed with have pharmacological exercises for example, such that phenolic Compounds, Alkaloids, Terpenoids, Sterols, Glycosides, Flavonoid, Resins, Anthroquinone, Saponins, Tannins. Eichhornia crassipes (water hyacinth) could a chance to be usefully utilized will extricate supplements from sewage. It is likewise demonstrated advantageous in treating effluents dirtied for lethal overwhelming metals for example, $\mathrm{Cd}, \mathrm{Cu}$ What's more Ni. Water hyacinth likewise indicated mitigating Activity, anticancer Activity, Anticorrosion Activity, cell reinforcement Activity, Wound recuperating Activity, antimicrobial activity, antimicrobial action Larvicidal action. Therefore, this audit article will be an accumulation of the updated data viewing Phytoremediation, optional Metabolities, pharmacological status about water hyacinth.
\end{abstract}

Key words: Water Hyacinth, Eichhornia crassipes, Phytoremediation, Phytochemical

\section{Introduction}

Around the world, there is a expanding pattern in zones about land, surface waters What's more groundwater influenced by sullying from industrial, military Furthermore agri exercises (Oncel et al., 2000) Possibly because of ignorance, absence of vision, alternately heedlessness. Those build-up from claiming poisonous pollutants (metals, radionuclides and natural contaminants for soil, surface water Also ground water) not best influences regular assets as well as makes An real strain looking into biological communities. Remediation from claiming defiled locales utilizing accepted practices, for example, such that 'pumpand-treat' Furthermore 'dig-and-dump' techniques, will be often expensive, need constrained potential, furthermore will be normally just relevant on little territories. Additionally, these customary methodologies to remediation frequently make those soil fruitless Furthermore unsatisfactory to farming Also different employments Eventually Tom's perusing destroying that micro environment. Subsequently there is the requirement will create What's more apply alternative, naturally callous advances (ESTs), bringing under account the possible conclusion utilization of the webpage once it need been remediated.

Phytoremediation is:

- Cheeper, solar energy driven cleanup technique.
- Most useful at sites with shallow, low levels of contamination.

- Helpful in removing heavy metal contamination

- Effective with, or in some cases, in place of mechanical cleanup methods.

How does phytoremediation works:

There need aid a few approaches in which plants need aid used to clean up, alternately remediate, defiled destinations. On uproot pollutants from soil, silt or water, plants camwood break down, alternately degrade, natural pollutants alternately hold numerous Furthermore balance out metal contaminants by acting Concerning illustration filters alternately traps.

Those uptake about contaminants for plants happens essential through those root system, on which the central instruments for keeping contaminant poisonous quality are discovered. Those root framework gives a tremendous surface range that absorbs Also aggregates those water What's more supplements fundamental for growth, and also different non-essential contaminants. Specialists would discovering that the utilization of trees (rather over littler plants) will be successful for treating deeper sullying as a result tree establishes infiltrate All the more profoundly under the ground. Done addition, deep-lying defiled ground water could make treated Toward pumping the water out

\section{${ }^{*}$ Corresponding Author:}

\section{Mr. Amit Pandey,}

Research Scholar, Dept. Of Botany,

Bundelkhand University, Kanpur Road,

Jhansi, India.

E-mail: pandeyamit0076@gmail.com

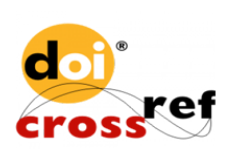


of the ground and utilizing plants with treat the sullying.

Plant roots also cause changes at the soil-root interface as they launch inorganic and natural compounds (root exudates) in the rhizosphere. these root exudates have an effect on the quantity and interest of the microorganisms, the aggregation and stability of the soil debris across the root, and the supply of the contaminants. Root exudates, via themselves can increase (mobilise) or lower (immobilise) at once or not directly the supply of the contaminants within the root quarter (rhizosphere) of the plant via adjustments in soil traits, launch of natural substances, adjustments in chemical composition, and/or growth in plantassisted microbial hobby.

Phytoremediation is an alternative or complimentary generation that can be used together with or, in a few cases in area of mechanical traditional easy-up technologies that frequently require high capital inputs and are labour and energy intensive. Phytoremediation is an in-situ remediation technology that utilises the inherent competencies of residing plant life. it's also an ecologically friendly, sun-power driven easy-up era, based totally at the concept of the usage of nature to cleanse nature.

Phytoremediation of Heavy metals by Eichhornia Crassipes

The toxicity of those heavy metals to flowers varies with individual metallic and concentrations. Induction of leaf chlorosis, discount of biomass manufacturing and nutritional pleasant has been discovered on vegetation grown in soils contaminated with slight stages of heavy metals (Clijsters et al., 1999).

The increase of E. crassipes in crude oil contaminated water influences the physico chemistry of the water thereby enhancing degradation of crude oil. Crude oil pollutants commonly result in an growth in $\mathrm{pH}$, temperature, conductivity, salinity and turbidity even though $\mathrm{pH}$ appears to be the maximum important parameter on this method. Phytoremediation however reduces the $\mathrm{pH}$, conductivity, temperature, salinity and turbidity of the water because of absorption of pollutants with the aid of the plant. A vast boom within the morphological parameters (plant peak, variety of leaves and leaf region) turned into found after 2 weeks and in addition growth had been determined at four weeks. At eight weeks and 12 weeks which the experiment lasted, the increase price reduced greatly since it turned into a limited experiment which received restricted daylight. Chlorosis of the leaves become additionally found and this can be an implication of the heavy metals absorbed by the plant. Cadmium in this case is toxic to the plant. Preferential accumulation of metals within the plant roots appears to be a generalized strategy to limit damage resulting from these factors within the plant (Ochekwu et al., 2013).

The variation in tolerance indices to the exceptional metals shows that genetically based totally tolerance may exist in vegetation that could continue to exist heavy metal infected habitat. (Lasat et al., 2000) cloned a excessive affinity $\mathrm{Zn}$ transporter expressed in Thlaspi caerulescens. The plant has been recognized as hyperaccumulator of $\mathrm{Zn}$. The differential accumulation of heavy metals via $E$. crassipes found on this observe will be because of the presence or absence of unique transporter for a specific element. An instantaneous proof for the sort of transporter would have to come from molecular studies. E. crassipes is a negative accumulator of Hg. (Qian et al., 1999) pronounced that Cyperus alternifolius, Spartina alterniflora and Juncus xiphioides had been terrible accumulators of $\mathrm{Hg}$. It showed that E. crassipes is a superb accumulator of $\mathrm{Zn}, \mathrm{Cr}, \mathrm{Cu}, \mathrm{Pb}, \mathrm{Ag}$, and $\mathrm{Cd}$. other research have additionally shown that the plant become an amazing accumulator of Cd (Muramoto and Oki 1983) and Cr (Lytle et al., 1996).

Phytoremediation ability of water hyacinth Eichhornia crassipes, for the elimination of $\operatorname{copper}(\mathrm{Cu})$ and Cadmium (Cd). The test confirmed that each $\mathrm{Cu}$ and $\mathrm{Cd}$ had consequences on plant relative boom. The plant at all of the concentrations used in the test removed approximately extra than $90 \%$ of $\mathrm{Cu}$ and $\mathrm{Cd}$. removal of metals from water was fast in particular inside the first 5 days. The accumulation of $\mathrm{Cu}$ and $\mathrm{Cd}$ in roots and stems multiplied with the initial awareness. in any respect ranges the flowers collected the best concentration of $\mathrm{Cd}$ in roots, whilst the best concentration of $\mathrm{Cu}$ was accumulated in stems. The biocencentration factor (BCF) of $\mathrm{Cu}$ turned into higher than that of $\mathrm{Cd}$ on the identical length, suggesting that the accumulation ability of Eichhornia crassipes for $\mathrm{Cu}$ become higher than that for $\mathrm{Cd}$ and will be used to treat waste-water infected with low $\mathrm{Cu}$ and $\mathrm{Cd}$ accumulations (Swain et al.,2014).

\section{Pharmacological study of Eichhornia Crassipes a) Anti-inflammatory Activity: The} formaldehyde brought about interest accomplished with the petroleum ether, ethyl acetate and aqueous extracts of E.crassipes has proved to be a systematic evidence for the usage of this plant in the treatment of inflammation. The presence of phytochemicals inside the extracts of this plant is probably the reason for the activity. among the studied extracts, the ethyl acetate extract showed higher antiinflammatory activity.

b) Anticancerous Activity: The Anticancerous Activity of methanol extract and the fractionated compounds (5 fractions) of Eichhornia species had been checked towards MCF-7 and HepG-2 cells by 
SRB assay as formerly mentioned (Freshney, 2002). Exponentially developing cells were accumulated using $0.25 \%$ trypsin EDTA and plated in ninety-sixwell plates at 1000 to 2000 cells/well. Result confirmed that the better ability of the extract towards cancer mobile traces in special HeLa and MCF-7 relative to all fractions from the identical extract, might be attributed to car-synergistic effect of those fractions in the same extract (Aboul-Enein et al., 2012; Shanab \& Shalaby, 2012).

c) Anticorrosion Activity: The received facts showed that, the addition of the 3 E. crassipes extracts (E-1, E-2, E-3) shifts the corrosion ability (Ecorr) to begin with slightly in the superb direction. Figures 1 and 2 represented the polarization curves of AZ31E in blank answer without and with eighty ppm of E1, E2, E3 and exceptional attention of E3, respectively. It is clear from this determine that in all of the 3 components, the icorr decreases with growing the concentration (Shanab \& Shalaby, 2012). analysis of the experimental spectra was made by great fitting to the corresponding equivalent circuit the use of Thales software program supplied with the laptop in which the dispersion formula appropriate to each model turned into used (El-Mehalawy et al., 2008) For this model, the electrode impedance is represented by using the subsequent switch characteristic (El-Shoubary, 2010).

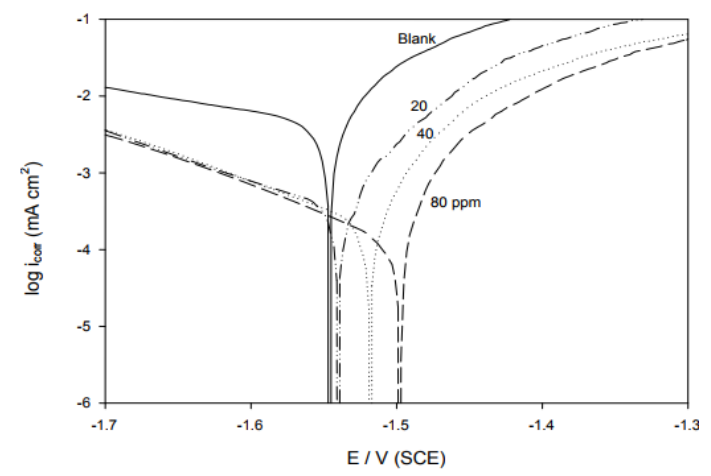

Figure 1. Dependence of RT on the concentration for AZ31E in $0.15 \mathrm{M} \mathrm{NaCl}$ containing E1, E2, and E3 (Shanab \& Shalaby, 2012)

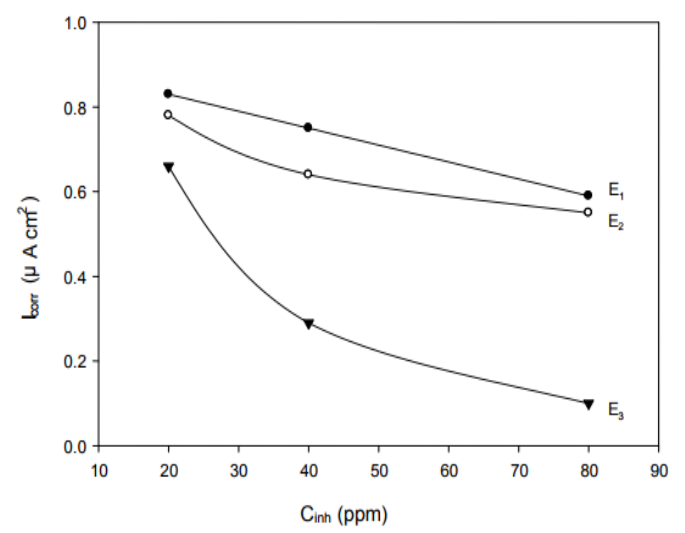

Figure 2. Polarization curves of AZ31E in $0.15 \mathrm{M}$ $\mathrm{NaCl}$ without and with $80 \mathrm{ppm}$ of E1, E2, and E3. (Shanab \& Shalaby, 2012)

d) Antioxidant Activity: The antioxidant hobby of water hyacinth extracts become evaluated with the aid of using the DPPH assay (Burits and Bucar, 2000). The antioxidant activity (at better attention, one hundred $\mu \mathrm{g} / \mathrm{ml}$ ) of ethyl acetate (E2) became extra than those of hexane (E1) and methanol (E3) (Shanab \& Shalaby, 2012).

e) Wound Healing Activity: The methanolic extract of water hyacinth leaves in the shape of an ointment, at different concentrations $(10 \%$ and $15 \%, \mathrm{w} / \mathrm{w}$ of leaf extract in a easy ointment base) had been investigated for his or her wound healing capacity in an excision experimental version of wounds in rats. The treatments confirmed better wound contraction capability that was appreciably greater than that of the control (Ali et. al., 2010).

f) Antimicrobial activity: The methanol extract showed antibacterial and antifungal and anti-algal sports by means of using disc diffusion method. Water hyacinth extract showed antimicrobial pastime towards $S$. aureus, E. coli, Penicillium and $A$. niger (Zhou et al., 2009). The methanolic extract of water hyacinth showed pastime in opposition to $A$. alternata, A. flavus, F. oxysporum, R. solani, and $X$. compestries (Vadlapudi, 2010).

g) Larvicidal Activity: The crude hexane, ethyl acetate, methanol, benzene and aqueous leaf extracts of Eichhornia crassipes had been examined for the larvicidal efficacy towards the early fourth instar larvae of Culex quinquefasciatus at concentrations of $62.5,125,250$ and $500 \mathrm{mg} / \mathrm{L}$. Mortality changed records after 48 hours. Amongst the crude leaf extracts of Eichhornia crassipes tested, the hexane and methanol extract changed into observed to be the best at 62.5 and $500 \mathrm{mg} / \mathrm{L}$ and LC50 values had been 80.54 and $137.50 \mathrm{mg} / \mathrm{L}$ respectively (Annie et al., 2015).

\section{Secondary Metabolities in Eichhornia Crassipes \\ a) Phenolic Compounds: Phenolic compounds are detected in the leaves (Anjana \& Matai, 1990; Center \& Wright, 1991), methanol extract (Shanab et al., 2010; Kandukuri et al., 2009) aqueous extract (Lata \& Dubey, 2010) and ethyl acetate extract (Jayanthi et al., 2011) of water hyacinth.}

b) Alkaloids: Alkaloids are also present in Plant (Ndubuisi et al., 2007; Kandukuri et al., 2009; Lata \& Dubey, 2010; Jayanthi et al., 2011)

c) Terpenoids: Triterpenoids are a massive elegance of herbal isoprenoids found in better flora, which showcase a huge range of biological sports (Isvett et al., 2002). Terpenoids were found in a range of extracts of water hyacinth (Shanab et al., 
2010; Ndubuisi et al., 2007; Kandukuri et al., 2009; Lata \& Dubey, 2010; Jayanthi et al., 2011).

d) Sterols: Number of researchers have reported sterols in various Water hyacinth extract (Kandukuri et al., 2009; Lata \& Dubey, 2010; Jayanthi et al., 2011)

e) Glycosides: Glycosides (Ndubuisi et al., 2007), also known as cardiac glycosides (Lata \& Dubey, 2010), were found in the chloroform and aqueous extracts of the plant.

f) Flavonoid: Reported in Petroleum ether and Aqueous Extract of Water Hyacinth (Jayanthi et al., 2011)

g) Resins, Anthroquinone, Saponins, Tannins: Resins (Viado,2006) are found in waterhyacinth. Saponin in chloroform and methanol extracts (Ndubuisi et al., 2007; Kandukuri et al., 2009), and anthroquinone within the chloroform extract (Lakshminarayana, 1984) of waterhyacinth have been found. The aqueous extract of water hyacinth shoot includes Phlobatannin, Quinone, Anthraquinone and Cardiac glycosides, whereas Phlobatannin and Cardiac glycosides are absent within the rhizome (Lata \& Dubey, 2010).

h) Carbohydrates: Carbohydrate is reported to have several roles in living things, including the garage and transport of energy (starch, Glycogen) and structural components (cellulose in plants, chitin in animals). Additionally, carbohydrates and their derivatives play important roles inside the running procedure of the immune system, fertilization, pathogenesis, blood clotting and development (Madziga et al., 2010). It's far found in Acid handiest (Jayanthi et al., 2011).

\section{Conclusion}

As per the Study it is concluded that Water hyacinth is used in different field. The fast growth of population has caused rapid in increase the domestic sewage pollution. So it is used for the removal of heavy metal like $\mathrm{Cd}, \mathrm{Ni}, \mathrm{Cu}$ from Industrial effluents or waste water. Number of parameters like BOD, DO, COD, TDS, EC, Nitrogen, phosphate etc has been minimized by using water hyacinth.

\section{References}

1. Aboul-Enein AM, Shanab S, Shalaby EA, El-Shemy HA. Cytotoxicity and antioxidant capacity of Eichbornia crassipes Extracts., under press in J. Enz. Inh. Med. Chem, 2012.

2. Ali H, Lata N, Ahi J, Ganesh N. Evaluation of wound-healing activity of Eichbornia crassipes: A novel approach. Drug Invention Today. 2010, 2, 212-214.
3. Anjana B, Matai S. Composition of Indian aquatic plants in relation of utilization as animal forage. Journal of Aquatic Plant Management, 1990, 28, 6973.

4. Annie SW, Raveen R, Paulraj MG, Samuel T, Arivoli S. Screening of Eichhornia crassipes (Mart.) Solms (Pontederiaceae) crude leaf extracts for larvicidal efficacy against the filarial vector Culex quinquefasciatus Say (Diptera: Culicidae). IJMR 2015; 2 (4), 43-48.

5. Burits M, Bucar F. Antioxidant activity of Nigella sativa essential oil. Phtother. Res., 2000, 14, 323-328.

6. Center TD, Wright AD. Age and phytochemical composition of Water hyacinth (Pontederiaceae) leaves determine their acceptability to Neochetina eichhorniae (Coleoptera: Curculionida). Environmental Entomology, 1991, 20, 323-334.

7. Clijsters, H., Cuypers, A., \& Vangronsveld, J. Physiological response to heavy metals in higher plants; Defence against oxidative stress. Zeitscbrift für Naturforschung, 1999, 54c, 730-734.

8. El-Mehalawy AA, Gebreel HM, Rifaat HM, ElKholy IM, Humid AA. Effect of antifungal compounds produced by certain bacteria on physiological activities of human and plant pathogenic fungi. J. Appl. Sci. Res., 2008, 4(4), 425432

9. El-Shoubary MEE. The antimicrobial activity of some seaweeds collected from Alexanderia coast. M. Sc. Thesis, Botany and Microbiology department, Faculty of Science, Tanta University, Tanta, Egypt, 2010, 155.

10. Freshney RI. Cell line provenance. Cytotechnology, 2002, 39, 55-67.

11. Gomati Swain, S. Adhikari and P. Mohanty. Phytoremediation of Copper and Cadmium from Water Using Water Hyacinth, Eichhornia Crassipes. IJAST,2014, 2(1), 1-7.

12. Isvett J. Flores-Sánchez, Jaime Ortega-López, María del Carmen Montes-Horcasitas and Ana C. RamosValdivia. Biosynthesis of Sterols and Triterpenes in Cell Suspension Cultures of Uncaria tomentosa, Plant Cell Physiol., 2002, 12,1502-1509.

13. Jayanthi P, Lalitha P, Shubashini KS. Phytochemical investigation of the extracts and the solvent fractionates of the aqueous extract of Eichbornia crassipes. Journal of Pharmacy Research, 2011, 4, 1405-1406.

14. Kandukuri V, Vinayasagar JG, Suryam A, Singara Charya MA. Biomolecular and phytochemical analyses of three aquatic angiosperms. African Journal of Microbiology Research, 2009, 3, 418-421.

15. Lakshminarayana G, Sundar Rao K, Pantulu AJ, Thyagarajan G. Composition of lipids in roots, stalks, leaves and flowers of Eichbornia crassipes (Mart.) Solms. Aquatic Botany, 1984, 20, 219-227. 
16. Lasat, MM, Pence, NS, Garvin DF, Ebbs SD, \& Kochian, LV. Molecular physiology of zinc transport in the $\mathrm{Zn}$ hyperaccumulator Thlapsi caerulescens. Journal of Experimental Botany, 2000, 51, 71-79.

17. Lata N, Dubey V. Preliminary phytochemical screening of Eichhornia crassipes: the world's worst aquatic Weed. Journal of Pharmacy Research, 2010, 3,1240-1242.

18. Lytle, CM, Zayed, A., Terry, N., \& Lytle, FW. Phytoconversion of $\mathrm{Cr}$ (iv) to $\mathrm{Cr}$ (iii) by water hyacinth: $\mathrm{A}$ case for phytoremediation. Abstracts of the annual combined meeting of the Ecological Society of America on Ecologists/Biologists as problem solvers providence, RI, 1996.

19. Madziga HA, Sanni $S$ and Sandabe UK Phytochemical and Elemental Analysis of Acalypha wilkesiana Leaf, Journal of American Science, 2010, $11,510-514$.

20. Muramoto S, \& Oki Y. Removal of some heavy metals from polluted water by water hyacinth (Eichbornia crassipes). Bulletin of Environmental Contamination and Toxicology, 1983, 30: 170-177.

21. Ndubuisi JA, Emeka EO, Ukiwe LN. Physicochemical properties of chloroform extract of water hyacinth (Eichbornia crassipes). African Journal of Plant Science and Biotechnology, 2007, 1, 40-42.

22. Ochekwu, Edache Bernard; Madagwa, Blessing. Phytoremediation potentials of water Hyacinth. Eicbhornia Crassipes (mart.) Solms in crude oil polluted water. J. Appl. Sci. Environ. Manage. 2013, 17 (4), 503-507.

23. Oncel I, Kele Y, \& Ustun, AS. Interactive effects of temperature and heavy metal stress on the growth and some biochemical compounds in wheat seedlings. Environmental Pollution, 2000, 107(3), 315320.
24. P. Jayanthi, P. Lalitha, R. Sujitha and A. Thamaraiselvi. Anti-Inflammatory Activity of The Various Solvent Extracts of Eichbornia crassipes (Mart.) Solms. International Journal of Pharm Tech Research, 2013, 5 (2), 641-645.

25. Qian JH, Zaved A, Zhu YL, Yu M, \& Terry N. Phytoaccumulation of trace elements by wetland plants: III. Uptake and accumulation of ten trace elements by twelve plant species. Journal of Environmental Quality, 1999, 28, 1448-1455.

26. Sanaa MM, Shanab and Emad A. Shalaby. Biological activities and anticorrosion efficiency of water hyacinth (Eichhornia crassipes). Journal of Medicinal Plants Research, 2012, 6(23), 3950-3962.

27. Shanab SMM, Shalaby EA, Lightfoot DA, El-Shemy HA. Allelopathic effects of water hyacinth [Eichhornia crassipes], 2010, 5.

28. Vadlapudi V. In vitro antimicrobial activity of methanolic extract of selected Indian medicinal plants. Pharmacophore, 2010,1, 214-219.

29. Viado G. Phytochemical, microbiological screening and pharmacologic testing of waterhyacinth (Eichbornia crassipes Linn) and Katakataka (Kalanchoe pinnata Linn). Thesis. University of Northern Philippines, 2006.

30. Zhou B, Jin-Ping P, Guo J, Tang S. Research on the antibacterial activities of extract from Eichbornia crassipes. Jiangsu Journal of Agricultural Science, 2009, 25, 547-550.

\section{Cite this article as:}

Mohan J., Mohan N., Narendra Babu Shakya; Amit pandey \& Raghvendra Chauhan. A review on secondary metabolites, pharmacological status and phytoremediation to treat water hyacinth. Annals of Plant Sciences 7.4 (2018) pp. 2170-2174.

do http://dx.doi.org/10.21746/aps.2018.7.4.1 